Research Article

\title{
Work Engagement During Pandemic: Is Organizational Trust Still Relevant?
}

\author{
Hyder Ali Khawaja ${ }^{1}$ and Mustajab Ahmed Soomro,", \\ ${ }^{1}$ Lund University, Sweden \\ hyder_ali.khawaja.246@lu.se \\ ${ }^{2}$ University of Tasmania, Australia \\ mustajabahmed.soomro@utas.edu.au \\ *Correspondence: mustajabahmed.soomro@utas.edu.au
}

Received: $2^{\text {nd }}$ February 2021; Accepted: 15 $5^{\text {th }}$ April 2021; Published: $1^{\text {st }}$ May 2021

Abstract: In the present study, we tested the relationship between organizational trust and engagement. The study investigated how the three factors of organizational trust including trust in management, trust in supervisor and trust in coworkers can predict work engagement. The study collected data through sampling employees working in the retail food businesses in Sweden via social media. The study applied structural equation modelling on the final sample of 199 to test the three factors of organizational trust and their relationship with work engagement and found significant positive results for all. The study found that employees who expressed trust in the top management resulted in enhancing their work engagement. Furthermore, employees who had trust in their immediate supervisors for their facilitation, support and acknowledgement were also able to boost their engagement. Lastly, trust in coworkers also helped employees to enhance their work well-being, in other words predicting work engagement. The study offers discussion on the findings, implications, and recommendations for future research.

Keywords: Organizational Trust; Management Trust; Supervisor Trust; Coworker Trust; Work Engagement

\section{Introduction}

To survive and sustain in the competitive environment, especially in turbulent times like Pandemic, organizations need to retain competitive workforce capable and willing to do more (Darwish et al., 2020; Meynaar et al., 2021). For this, the corporate world is seen focusing less on conventional elements and more on making employees passionate about the work so that they invest the best of their capabilities at work (Chughtai \& Buckley, 2011), in other words, work engagement. Studies have reported that employees who are engaged with work strive the hardest and give better results compared to others (Bakker et al., 2012). Research also indicates that work engaged bring better performance and organizational outcomes, which makes the business give better outcomes for their customers (Kašpárková et al., 2018). Work engagement is a work-based state of mind that boosts dedication, vigor, and absorption towards work (Schaufeli et al., 2002). Research in the past has indicated several predictors of work engagement. In this, one factor that has been gaining much attention is organizational trust (Oguegbe \& Edosomwan, 2021; Shockley-Zalabak et al., 2000). Studies suggest that employees' level of trust in management, immediate supervisor and coworkers can boost employees` positive outcomes (Nguyen et al., 2020). However, limited studies have

Hyder Ali Khawaja and Mustajab Ahmed Soomro, “Work Engagement During Pandemic: Is Organizational Trust Still Relevant?", Annals of Contemporary Developments in Management \& HR (ACDMHR), Print ISSN: 2632-7686, Online ISSN: 2632-7694, pp. 1-10, Vol. 3, No. 2, $1^{\text {st }}$ May 2021, Published by International Association of Educators and Researchers (IAER), DOI: 10.33166/ACDMHR.2021.02.001, Available: http://acdmhr.theiaer.org/archive/v3/v3n2/p1.html. 
tested the importance and significance of organizational trust factors in predicting work engagement (Chughtai \& Buckley, 2011; Nigah et al., 2012). Particularly, are these trust factors still relevant to enhance employee work well-being like engagement in the time of global crisis such as COVID-19? Therefore, the present study attempted to test how the three factors of organizational trust correlate and translate into predicting work engagement. The later sections discuss the concept of work engagement, predictors of engagement and its benefits, organizational trust, its significance and vitality. Following to this, the next section provides details about analysis and results from the structural equation modelling for the three hypotheses tested in the present study.

\section{Literature Review}

\subsection{Work Engagement}

Work engagement is denoted as a psychological work-based state that brings passion, immersion, energy and commitment towards work (Schaufeli et al., 2002). Work engagement has received huge empirical attention recently (E.g., AlZgool et al., 2020 due to scholars eyeing the concept of positive work psychology. Engaged individuals are said to be working with more dedication and commitment compared to others (Teo et al., 2020). Academic literature outlines two approaches towards engagement. The first approach is the practitioner approach, whereby the concept is generally referred as job or employee engagement. Therein, practitioners denoting it as job engagement describe it as an individual's enthusiasm and immersion in his/her job (Roberts \& Davenport, 2002). Accordingly, practitioners referring it as employee engagement describe it as an employee`s involvement in the work with high enthusiasm and emotional connectivity (Harter et al., 2002; Mohammad et al., 2020). On the academic side, the concept is more popular as work engagement and was first coined by Kahn (1990) who defined it as "the harnessing of organizational members' selves to their work roles; in engagement, people employ and express themselves physically, cognitively and emotionally during role performances" (p. 694). According to the author, individuals experiencing work engagement express psychical involvement and emotional connectivity with the work. These explanations lead us to understand engagement as a positive fulfilling psychological state that makes individuals bring their best in work.

Work engagement is found to be more promising when it comes to employee behaviors and outcomes. Typically, employees who are engaged perform better than those who are just motivated and/or satisfied with the work (Giallonardo et al., 2010). This can be seen as why Kahn (1990; 1992) has categorically distinguished between engaged and disengaged individuals whereby he mentions that despite the presence of other positive behaviors, employees who are not engaged will not perform or produce results compatible the one who are engaged. Another important conceptualization of engagement comes from Saks (2006) who has denoted engagement as a psychological presence of an individual in a particular role. The author further asserts that most employees showcasing such behavior often express job as well as organizational engagement. Talking about engagement, Maslach and Leiter (1997) have also given an important explanation whereby they talk about burnout, which damages engagement.

The authors have highlighted an important prospect for organizations suggesting that to maintain high levels of engagement; there is a need to eradicate burnout and work exhaustion. Similar assertions have also been forwarded by Ahmed et al. (2017) and Ahmed et al. (2019) by highlighting how job demands and workload can affect work engagement. Talking about the benefits of engagement in particular, empirical evidence suggests that engagement workers are high performers (Saks, 2006). Another study also reported a significant role of work engagement in boosting job satisfaction (Sohrabizadeh \& Sayfouri, 2014). Remarkably work engagement is also found significant in boosting career satisfaction (Ilkhanizadeh, S., \& Karatepe, O. M. (2017) and improvement in the quality management practices (Heyns \& Boikanyo, 2019). Based on these proofs, we can understand how beneficial it can be for an organization to have an engaged workforce. 


\subsection{Drivers of Work Engagement}

After understanding the concept of work engagement and its significance, it becomes important to understand what actually predicts it. Critical appraisal of literature underlines the significance of job resources in boosting work engagement. Job resources are prospects of work that help individuals counter the work demands and achieve organizational goals (Demerouti et al., 2001). With this perspective, dozens of studies can be traced that have highlighted how different job resources can help boost work engagement. For example, some studies have indicated the significance of support at work in furthering work engagement (e.g., Hakanen et al., 2006; Ahmed et al., 2016)

Similarly, some studies have reported the significance of HR practices towards boosting work engagement (e.g., Awang et al., 2017; Ahmed et al., 2016; Geldenhuys et al., 2014). Accordingly, recent studies have also reported the significance of leadership styles in predicting work engagement (Breevart \& Bakker, 2018; Sarwar et al., 2020). These findings suggest that positive support, facilitation, and appreciation from leadership can help employees give the best towards work. Furthermore, there are personal resources that have been termed significant for predicting work engagement. Studies such as Xanthopoulou et al., 2007; 2009) have reported that personal resources such as self-efficacy and resilience can help boost work engagement. Personal resources are basically referred to as individual resources that help boost psychological well-being. These studies have reported that employees who are high in beliefs about them to be able to overcome obstacles can help boost work engagement. Similar assertions have been forwarded by study of Li et al. (2017), thus confirming the role of personal resources towards enhancing work engagement. Moreover, personality traits have also been found to predict work engagement. For instance, study by Mosert and Rothman (2006) reported a significant impact of personality traits such as emotional stability, extraversion and conscientiousness towards harnessing the different aspects of work engagement. Similar assertions were also forwarded by Kim, Shin, and Swanger (2009). Conclusively, these studies outline different factors that can boost work engagement. Ranging from support at work to human resource practices to leadership styles and individual self-belief, critical appraisal of the literature discussed above highlights a wide array of factors that can help boost engagement.

\subsection{Organizational Trust}

One of the most popular definition by Mayer et al. (1995) denotes trust as "the willingness of a party to be vulnerable to the actions of another party based on the expectation that the other party will perform a particular action important to the trustor irrespective of the ability to monitor or control the other party" (p. 712). On a similar note, Rousseau et al. (1998) explanation to the concept of trust is also popular which defines it as "a psychological state comprising the intention to accept vulnerability based upon positive expectations of the intentions or behavior of another" (p. 395). Critical appraisal of both the definitions highlight two mutual elements, expectations and willingness. The first party therein showcases positive expectations in the other party and remains open for any vulnerability from the other party. Important to note that this openness to vulnerability from the other part is based on the view that the latter party if honest, reliable, and competent in handling matters (Mishra \& Mishra, 2013).

Trust is generally discussed with four factors, namely competence, openness, concern, and reliability. There, competence denotes to individual capability and expertise to perform a certain task. When we talk about trust at work, for instance, in connection to leaders, it can be seen as their ability to be able to do the right things in the right manner. (Bashir et al., 2020). In this, employees will express trust in their leaders when they believe in them being skilled and capable. Similar can be seen when it comes to immediate supervisors, where subordinates are likely to show trust in them when they perceive them as skilled, capable of making good decisions, and proficiently solving work problems. Similarly, competence in connection to team members can also play a significant role. In this, when an employee views his/her 
subordinates to be significant in their capabilities, able to do the work, and perform better and reliable in work prospects to assist in achieving the organization`s vision (Bartram \& Casmir, 2007).

The term openness refers to the prospect whereby people put themselves at risk by exchanging sensitive information with one another. Openness is an important element that helps in developing a positive sense of working. Organizations that value openness with clear communication and direction help their employees to trust them in their work and approach (Costa et al., 2009). When employees are open to sharing information with the sense that they will not be manipulated or will not potentially face any negative consequences, it makes them express trust in their leaders, supervisors, and members. Trust has a lot to do with openness and people at work feel comfortable when they experience such elements, particularly when it comes to the employees they directly interact such as leaders, immediate supervisors, and colleagues. Another important factor of trust is concern, whereby the party should believe that the interacting party will not misuse or take any kind of unwarranted advantage intentionally. This prospect suggests that the trust can be developed only when the self-interest is balanced and the individual will not be taken for any misuse by other parties for their own interests. (Liu et al., 2005; Oosthuizen et al., 2018). Furthermore, the following entity is reliability which means one does what exactly he/she aims to do and. This principally refers to keeping the promises and making sure the things are done as they were described and detailed to others. Reliable behavior is essential to boost commitment and enhance positive behaviors and outcomes, particularly when it comes to leaders and managers (Karatepe, Ozturk \& Kim, 2019). Employees who perceive their work environment as reliable tend to showcase trust and work to give better results and outcomes.

\subsection{Trust and Work Engagement}

It is logical to state that trust in top management, supervisor, and coworker will be related to individual work engagement. For instance, leaders (top management) have a greater responsibility to boost employee morale, guide them, and show reliable behavior capable of leading the organization and work. Therefore, when employees view them as capable of performing these roles effectively, it will energize them to show connectivity, passion, and dedication towards the work, in other words predicting work engagement (Hassan \& Ahmed, 2011). Accordingly, trust in immediate supervisors can boost employee results (Chughtai et al., 2015), where they are expected to facilitate subordinates, encourage them, help them in problem-solving and recognize their efforts without any manipulation, thus predicting work engagement. Similarly, studies also suggest that coworkers have a considerable role to play when it comes down to how employees work and perform. Study by Nigah et al. (2012) has highlighted this and suggested its importance in predicting work engagement. The study mentions that good colleagueship can boost psychological capital, which aids in employees' work engagement. Although, there are limited evidence on how all these three factors are important in engaging retail workers in Sweden. More importantly, how and to what extent trust factors are relevant and important in the ongoing Pandemic is another significant gap.

\section{Methodology}

Structural equation modelling using Smart PLS 2.0 was used to assess the model and test the significance of the three hypotheses (Ringle et al., 2005). Based on the recommendation (Hair et al., 2016) two-step approach was used. In the first step, we tested to confirm the model in terms of its reliability and validity. In the second step, we tested the three relationships as depicted from the three hypotheses.

\subsection{Sampling}

An online survey was done to collect primary data for the present study through social media. Participants working in the retail food businesses such as Café, restaurants, and bars to respond to the 
questionnaire. The responses were welcomed from January to March 2021. A total of 216 responses were received via Google Forms. After discarding 17 inappropriate responses, 199 were used for model and hypotheses testing.

\subsection{Scales}

Trust in management was tested by using the scale by Schoorman et al. (2007). Trust in supervisor was tested by adapting the De Dremer and Tyler (2007) scale and trust in coworker by Parker et al. (2006). Lastly, work engagement was tested by adapting UWES scale (Schaufeli et al., 2006). We used a 5-point likert scale for responses ranging from strongly agree to strongly disagree.

\section{Data Analysis and Assessment}

\subsection{Assessment of Measurement Model}

In the measurement model assessment, we assessed average variance extracted (AVE) and composite reliability scores for all the variables followed by the individual item loadings. Following the recommendations of Chin (1998), we maintained the 0.50 threshold for AVE and 0.70 for composite reliability (Bagozzi et al., 1991). Furthermore, we maintained the threshold of 0.50 for individual item loadings for which some of the items from work engagement were deleted due to low loadings. The results for the measurement model tests are presented in Table 1 below:

Table 1. AVE, CR and Loadings

\begin{tabular}{|c|c|c|c|}
\hline Variable & AVE & Composite Reliability & Loadings \\
\hline Trust in Management & 0.5414 & 0.9338 & \\
\hline TM1 & & & 0.7571 \\
\hline TM10 & & & 0.7583 \\
\hline TM11 & & & 0.7923 \\
\hline TM12 & & & 0.7488 \\
\hline TM2 & & & 0.7827 \\
\hline TM3 & & & 0.7550 \\
\hline TM4 & & & 0.7517 \\
\hline TM5 & & & 0.6890 \\
\hline TM6 & & & 0.7682 \\
\hline TM7 & & & 0.6808 \\
\hline TM8 & & & 0.6605 \\
\hline TM9 & & & 0.6689 \\
\hline Trust in Supervisor & 0.6173 & 0.8256 & \\
\hline TS1 & & & 0.8397 \\
\hline TS2 & & & 0.8767 \\
\hline TS3 & & & 0.6149 \\
\hline Trust in Coworker & 0.7355 & 0.9174 & \\
\hline TC1 & & & 0.8144 \\
\hline TC2 & & & 0.8815 \\
\hline TC3 & & & 0.8798 \\
\hline TC4 & & & 0.8530 \\
\hline Work Engagement & 0.5730 & 0.8890 & \\
\hline WE1 & & & 0.6894 \\
\hline WE2 & & & 0.7011 \\
\hline WE4 & & & 0.7891 \\
\hline WE5 & & & 0.8296 \\
\hline WE7 & & & 0.7866 \\
\hline WE9 & & & 0.7356 \\
\hline
\end{tabular}

In the measurement model, we also tested the discriminant validity based on Fornell and Larcker (1981) recommendations. The authors have recommended to test the square root of AVE scores in a cross table to ensure that the values are higher than the corresponding figures. In this test, we found square root 
scores higher, hence it confirmed the discriminant validity of the model. The results of discriminant validity are provided in Table 2 below where the BOLD values showing the square root of AVE scores.

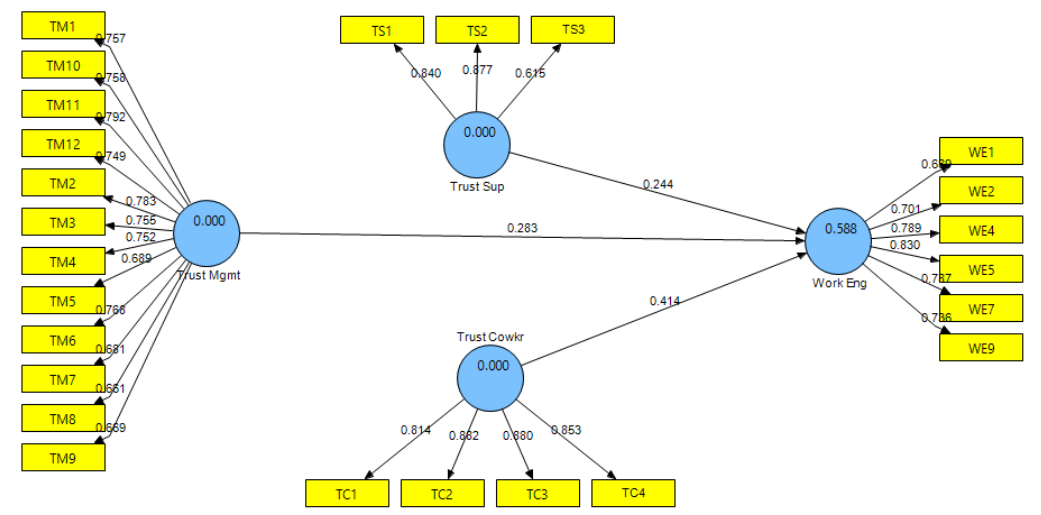

Figure 1. Measurement Model Assessment

Table 2. Discriminant Validity

\begin{tabular}{ccccc}
\hline Variable & $\begin{array}{c}\text { Trust in } \\
\text { Coworker }\end{array}$ & Trust in Management & $\begin{array}{c}\text { Trust in } \\
\text { Supervisor }\end{array}$ & $\begin{array}{c}\text { Work } \\
\text { Engagement }\end{array}$ \\
\hline Trust in Coworker & $\mathbf{0 . 8 5 7 6}$ & & & \\
Trust in Management & 0.4650 & $\mathbf{0 . 7 3 5 8}$ & & \\
Trust in Supervisor & 0.3326 & 0.7237 & $\mathbf{0 . 7 8 5 6}$ & \\
Work Engagement & 0.6273 & 0.6525 & 0.58702 & $\mathbf{0 . 7 5 6 9}$ \\
\hline
\end{tabular}

\subsection{Assessment of Structural Model}

After confirming the model, we tested the significance of hypothesized relationships. The results of the bootstrapping approach with 2500 bootstraps reported a significant positive relationship between trust in management and work engagement. Therefore we conclude support for hypothesis one $(\beta=0.2830$; $t$ value $=4.5065$ ). In addition, the bootstrap results also reported a significant positive relationship between trust in supervisor and work engagement. Therefore we conclude support for hypothesis two $(\beta=0.2442$; $\mathrm{t}$-value $=3.8145$ ). Furthermore, the bootstrap results also reported a significant positive relationship between trust in coworker and work engagement. We, therefore also conclude support for hypothesis three $(\beta=0.4144 ; \mathrm{t}$-value $=6.819)$.

Table 3. Results

\begin{tabular}{cccc}
\hline & Original Sample (O) & Standard Error (STERR) & T Statistics (| O/STERR |) \\
\hline Trust in Management $->$ Work Eng & 0.283028 & 0.062803 & 4.506588 \\
Trust inSupervisor $->$ Work Engagement & 0.244285 & 0.064041 & 3.814535 \\
Trust in Coworker $->$ Work Engagement & 0.414472 & 0.060781 & 6.819085 \\
\hline
\end{tabular}

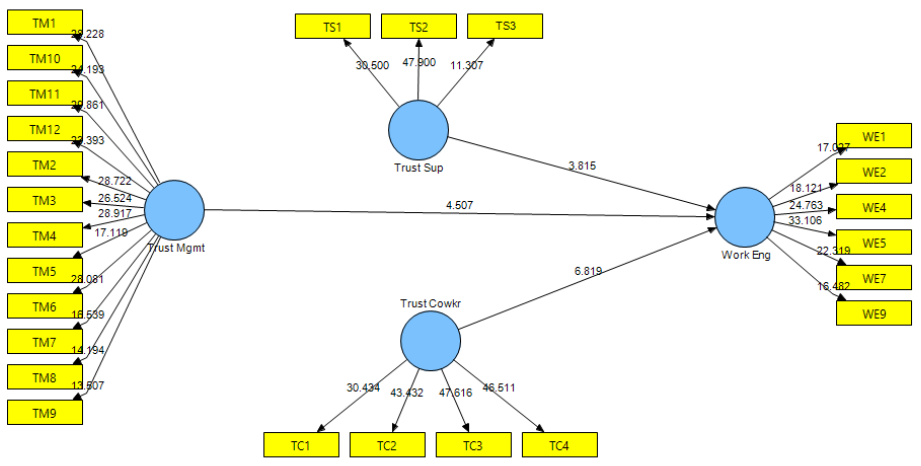

Figure 2. Bootstrap Results and Hypotheses Testing 


\section{Discussion, Implications and Recommendation}

The results reported in table 3 conclusively suggest the significance of organizational trust and employees' work engagement association. The findings indicate that when employees view their top management, immediate supervisors, and coworkers as trustworthy, reliable, and dependable, it augments their connectivity, immersion, and vigor towards work. The study has found that organizational trust is important for employees to give their best work with full dedication and passion. The findings support the claims of past studies (Butler \& Cantrall, 1984; Bartram \& Casmir, 2007; Karatepe, Ozturk \& Kim, 2019), on the importance of trust factors in predicting positive employee outcomes. In particular, the findings of hypothesis 1 confirm the results of Hassan and Ahmed (2011) on the importance of trust in top management and work engagement relationships.

Furthermore, trust in supervisors was also found significant in predicting work engagement and appeared logical to understand. Supervisors are expected to recognize, appreciate, and facilitate employees (Macey \& Schnider, 2008), which potentially enhance individual belief in their capabilities, resulting in them working with a high level of engagement (Llorens et al., 2007). Accordingly, the findings support the assertion of trust in coworkers and its role in predicting work engagement. The results suggest that employees ' faith in their coworkers as supportive and no manipulative and positive with high team spirit can further work engagement. The finding supports the conclusion of Chughtai and Buckley (2011), outlining how trust in coworkers can boost work engagement. In total, the findings of the present study support.

Based on the findings of the study, we imply that organizational trust is an important and relevant feature to boost work engagement. The study result also implies coworker support to be most important in predicting work engagement followed by trust in management. This hence infers how important it is for organizations to pay attention to these factors. The study has also confirmed the importance of organizational trust to predict work engagement in the ongoing crisis period as well. Contextually, the study has also implied that organizational trust, including trust in management, supervisor, and coworkers, is perceived as important in the retail food businesses in Sweden to boost employees' work engagement. For practice, we imply, based on the findings of the present study, that organizational trust is an important element, and businesses need to consider assessing and exploring if their employees have trust in their management, supervisors and colleagues to enable them to bring the best at work. Training and coaching programs (Sung \& Choi, 2018) may be used to assist managers, supervisors, and employees in general to understand its significance. Furthermore, for leaders (top management), consultation services (Winum et al., 1997), may be used to help them learn how they can showcase trust in employees to boost their work well-being. In addition, organizations may also encourage employees to show engagement and reward employees who express more connectivity and immersion towards the company and work.

\subsection{Contributions of the Study}

We, in the present study, attempted to address a few gaps in the literature and make important contributions. First, the current study tested the role of three factors or organizational trust towards predicting work engagement during the Pandemic. The study tried to highlight if trust factors are equally relevant and significant in the ongoing period of crisis. Second, we tested how these factors are related to the work engagement of retail workers in the food business (restaurants) in Sweden, where a major research gap existed. Third, we attempt to highlight the likely role of organizational trust factors for researchers and the corporate world to realize if it can boost employees`work well-being. 


\subsection{Limitations and Scope for Future Research}

The current study has three significant limitations. First, we conducted the study with a cross-sectional approach, which limits causal inferences. Researchers in the future, therefore may consider longitudinal studies. Second, the study did not test any mediating or moderating effect in the model, and therefore, research studies may find it interesting to extend the model by incorporating mediator/moderator(s). Third, organizational trust factors explained $58.8 \%$ variance towards work engagement (R20.588). Therefore, research studies in the future may also work on testing other factors and their direct association with employees` work engagement to help explain the remaining $41.2 \%$ variance.

\section{References}

Ahmed, U., Khalid, N., Islam, D. M. Z., \& Abro, Z. (2019). Abuse, emotions, and workload in the distribution business: Implications for employees' engagement. International Journal of Advanced and Applied Sciences, 6(8), 90-99.

Ahmed, U., Majid, A. H. A., \& Zin, M. L. M. (2016). HR Moderating HR: Critical link between Developmental HR Practices and work engagement in a Moderated Model. Management Review: An International Journal, 11(2), 4-22.

Ahmed, U., Majid, A. H. A., \& Zin, M. M. (2016). Moderation of meaningful work on the relationship of supervisor support and coworker support with work engagement. The Journal of Business Economics and Environmental Studies, 6(3), 15-20.

Ahmed, U., Shah, M. H., Siddiqui, B. A., Shah, S. A., Dahri, A. S., \& Qureshi, M. A. (2017). Troubling job demands at work: Examining the deleterious impact of workload and emotional demands on work engagement. International Journal of Academic Research in Business and Social Sciences, 7(6), 96-106.

Al-Hajri, S. A. (2020). Employee Retention in light of Green HRM practices through the Intervening role of Work Engagement. Annals of Contemporary Developments in Management \& HR (ACDMHR), 2(4), 10-19.

AlZgool, M. R. H., Ahmed, U., Pahi, M. H., \& Ammar, A. (2020). COVID-19 and Work Engagement: Understanding the Nexus of Leaders Emotional Intelligence, Self-efficacy and Resilience in the Banking Sector of Bahrain. Revista Argentina de Clínica Psicológica, 29(3), 568-586.

Awang, Z., Ahmed, U., Hoque, A. S. M. M., Siddiqui, B. A., Dahri, A. S., \& Muda, H. (2017). The Mediating Role of Meaningful Work in the Relationship Between Career Growth Opportunities and Work Engagement. In International Academic Conference on Business and Economics (IACBE 2017), Faculty of Economics and Management Sciences (FESP), Universiti Sultan Zainal Abidin (UniSZA), October 07 (Vol. 8).

Bagozzi, R. P., Yi, Y., \& Phillips, L. W. (1991). Assessing construct validity in organizational research. Administrative science quarterly, 36(3), 421-458.

Bakker, A. B., Demerouti, E., \& Xanthopoulou, D. (2012). How do engaged employees stay engaged. Ciencia $\mathcal{E}$ Trabajo, 14(1), 15-21.

Bartram, T., \& Casimir, G. (2007). The relationship between leadership and follower in-role performance and satisfaction with the leader: The mediating effects of empowerment and trust in the leader. Leadership \& Organization Development Journal. 28(1), 4-19.

Bashir, A., Rizvi, S. T. H., Chughtai, M. S., Paracha, U. K., \& Jashari, A. (2020). Followers' Faith Enhances Job Satisfaction that is induced by Trust Worthy Leaders: A Moderated Mediation Model of Communication Satisfaction. International Journal of Future Generation Communication and Networking, 13(2), 1453-1470.

Breevaart, K., \& Bakker, A. B. (2018). Daily job demands and employee work engagement: The role of daily transformational leadership behavior. Journal of occupational health psychology, 23(3), 338-349.

Breevaart, K., \& Bakker, A. B. (2018). Daily job demands and employee work engagement: The role of daily transformational leadership behavior. Journal of occupational health psychology, 23(3), 338-349.

Chin, W. W. (1998). The partial least squares approach to structural equation modeling. Modern methods for business research, 295(2), 295-336.

Chughtai, A. A., \& Buckley, F. (2011). Work engagement. Career Development International, 16(7), 684-705.

Chughtai, A., Byrne, M., \& Flood, B. (2015). Linking ethical leadership to employee well-being: The role of trust in supervisor. Journal of Business Ethics, 128(3), 653-663.

Costa, A. C., Bijlsma-Frankema, K., \& de Jong, B. (2009). The role of social capital on trust development and dynamics: implications for cooperation, monitoring and team performance. Social Science Information, 48(2), 199-228. 
Darwish, S., Ahmed, U., \& Pahi, M. H. (2020). Innovative work behavior during COVID-19 for medical representative in the pharmaceutical industry: Test of a moderation model in bahrain. International Journal of Pharmaceutical Research, 12(4), 1927-1934.

De Cremer, D., \& Tyler, T. R. (2007). The effects of trust in authority and procedural fairness on cooperation. Journal of applied psychology, 92(3), 639-649.

Demerouti, E., Bakker, A. B., Nachreiner, F., \& Schaufeli, W. B. (2001). The job demands-resources model of burnout. Journal of Applied psychology, 86(3), 499-512.

Fornell, C., \& Larcker, D. F. (1981). Evaluating structural equation models with unobservable variables and measurement error. Journal of marketing research, 18(1), 39-50.

Geldenhuys, M., Laba, K., \& Venter, C. M. (2014). Meaningful work, work engagement and organisational commitment. SA Journal of Industrial Psychology, 40(1), 01-10.

Giallonardo, L. M., Wong, C. A., \& Iwasiw, C. L. (2010). Authentic leadership of preceptors: predictor of new graduate nurses' work engagement and job satisfaction. Journal of nursing management, 18(8), 993-1003.

Hair Jr, J. F., Hult, G. T. M., Ringle, C., \& Sarstedt, M. (2016). A primer on partial least squares structural equation modeling (PLS-SEM). Sage publications.

Hakanen, J. J., Bakker, A. B., \& Schaufeli, W. B. (2006). Burnout and work engagement among teachers. Journal of school psychology, 43(6), 495-513.

Harter, J. K., Schmidt, F. L., \& Hayes, T. L. (2002). Business-unit-level relationship between employee satisfaction, employee engagement, and business outcomes: a meta-analysis. Journal of applied psychology, 87(2), 268-279.

Hassan, A., \& Ahmed, F. (2011). Authentic leadership, trust and work engagement. International Journal of Human and Social Sciences, 6(3), 164-170.

Heyns, M. M., \& Boikanyo, D. H. (2019). The effect of work engagement on total quality management practices in a petrochemical organisation. South African Journal of Economic and Management Sciences, 22(1), 1-13.

Ilkhanizadeh, S., \& Karatepe, O. M. (2017). An examination of the consequences of corporate social responsibility in the airline industry: Work engagement, career satisfaction, and voice behavior. Journal of Air Transport Management, 59, 8-17.

Kahn, W. A. (1990). Psychological conditions of personal engagement and disengagement at work. Academy of management journal, 33(4), 692-724.

Kahn, W. A. (1992). To be fully there: Psychological presence at work. Human relations, 45(4), 321-349.

Karatepe, O. M., Ozturk, A., \& Kim, T. T. (2019). Servant leadership, organisational trust, and bank employee outcomes. The Service Industries Journal, 39(2), 86-108.

Kašpárková, L., Vaculík, M., Procházka, J., \& Schaufeli, W. B. (2018). Why resilient workers perform better: The roles of job satisfaction and work engagement. Journal of Workplace Behavioral Health, 33(1), 43-62.

Kim, H. J., Shin, K. H., \& Swanger, N. (2009). Burnout and engagement: A comparative analysis using the Big Five personality dimensions. International Journal of Hospitality Management, 28(1), 96-104.

Li, M., Wang, Z., Gao, J., \& You, X. (2017). Proactive personality and job satisfaction: The mediating effects of selfefficacy and work engagement in teachers. Current Psychology, 36(1), 48-55.

Liu, C., Marchewka, J. T., Lu, J., \& Yu, C. S. (2005). Beyond concern-a privacy-trust-behavioral intention model of electronic commerce. Information \& Management, 42(2), 289-304.

Llorens, S., Schaufeli, W., Bakker, A., \& Salanova, M. (2007). Does a positive gain spiral of resources, efficacy beliefs and engagement exist?. Computers in human behavior, 23(1), 825-841.

Macey, W. H., \& Schneider, B. (2008). Engaged in engagement: We are delighted we did it. Industrial and Organizational Psychology, 1(1), 76-83.

Maslach, C., \& Leiter, M. P. (2008). The truth about burnout: How organizations cause personal stress and what to do about it. John Wiley \& Sons.

Mayer, R. C., Davis, J. H., \& Schoorman, F. D. (1995). An integrative model of organizational trust. Academy of management review, 20(3), 709-734.

Meynaar, I. A., Ottens, T., Zegers, M., van Mol, M. M., \& Van Der Horst, I. C. (2021). Burnout, resilience and work engagement among Dutch intensivists in the aftermath of the COVID-19 crisis: A nationwide survey. Journal of critical care, 62, 1-5.

Mishra, A. K., \& Mishra, K. E. (2013). The research on trust in leadership: The need for context. Journal of Trust Research, 3(1), 59-69. 
Mohammad, J., Quoquab, F., Thurasamy, R., \& Alolayyan, M. N. (2020). The effect of user-generated content quality on brand engagement: The mediating role of functional and emotional values. Journal of Electronic Commerce Research, 21(1), 39-55.

Mostert, K., \& Rothmann, S. (2006). Work-related well-being in the South African Police Service. Journal of Criminal Justice, 34(5), 479-491.

Nguyen, T., Pham, T., Le, Q., \& Bui, T. (2020). Impact of corporate social responsibility on organizational commitment through organizational trust and organizational identification. Management Science Letters, 10(14), 3453-3462.

Nigah, N., Davis, A. J., \& Hurrell, S. A. (2012). The impact of buddying on psychological capital and work engagement: An empirical study of socialization in the professional services sector. Thunderbird international business review, 54(6), 891-905.

Oguegbe, T. M., \& Edosomwan, H. S. (2021). Organizational-Based Self-Esteem and Organizational Identification as Predictors of Turnover Intention: Mediating Role of Organizational Trust. SEISENSE Journal of Management, 4(2), 56-71.

Oosthuizen, A., Rabie, G. H., \& De Beer, L. T. (2018). Investigating cyberloafing, organisational justice, work engagement and organisational trust of South African retail and manufacturing employees. SA Journal of Human Resource Management, 16(1), 1-11.

Parker, S. K., Williams, H. M., \& Turner, N. (2006). Modeling the antecedents of proactive behavior at work. Journal of applied psychology, 91(3), 636-652.

Ringle, C., Wende, S., \& Will, A. (2005). SmartPLS 2.0 (Beta). Hamburg, (www.smartpls.de).

Roberts, D. R., \& Davenport, T. O. (2002). Job engagement: Why it's important and how to improve it. Employment Relations Today, 29(3), 21-29.

Rousseau, D. M., Sitkin, S. B., Burt, R. S., \& Camerer, C. (1998). Not so different after all: A cross-discipline view of trust. Academy of management review, 23(3), 393-404.

Sarwar, H., Ishaq, M. I., Amin, A., \& Ahmed, R. (2020). Ethical leadership, work engagement, employees' well-being, and performance: a cross-cultural comparison. Journal of Sustainable Tourism, 28(12), 2008-2026.

Schaufeli, W. B., Bakker, A. B., \& Salanova, M. (2006). The measurement of work engagement with a short questionnaire: A cross-national study. Educational and psychological measurement, 66(4), 701-716.

Schaufeli, W. B., Salanova, M., González-Romá, V., \& Bakker, A. B. (2002). The measurement of engagement and burnout: A two sample confirmatory factor analytic approach. Journal of Happiness studies, 3(1), 71-92.

Schoorman, F.D., Mayer, R.C. and Davis, J.H. (2007). An integrated model of organizational trust: Past, present and future. Academy of Management Review, 32(2), 344-354.

Shockley-Zalabak, P., Ellis, K., \& Winograd, G. (2000). Organizational trust: What it means, why it matters. Organization Development Journal, 18(4), 35-48.

Sohrabizadeh, S., \& Sayfouri, N. (2014). Antecedents and consequences of work engagement among nurses. Iranian Red Crescent Medical Journal, 16(11), e16351.

Sung, S. Y., \& Choi, J. N. (2018). Effects of training and development on employee outcomes and firm innovative performance: Moderating roles of voluntary participation and evaluation. Human resource management, 57(6), 13391353.

Teo, S. T., Bentley, T., \& Nguyen, D. (2020). Psychosocial work environment, work engagement, and employee commitment: A moderated, mediation model. International Journal of Hospitality Management, 88, 102415.

Winum, P., Ryterband, E., \& Stephenson, P. (1997). Helping organizations change: A model for guiding consultation. Consulting Psychology Journal: Practice and Research, 49(1), 6-16.

Xanthopoulou, D., Bakker, A. B., Demerouti, E., \& Schaufeli, W. B. (2007). The role of personal resources in the job demands-resources model. International journal of stress management, 14(2), 121-141.

Xanthopoulou, D., Bakker, A. B., Demerouti, E., \& Schaufeli, W. B. (2009). Reciprocal relationships between job resources, personal resources, and work engagement. Journal of Vocational behavior, 74(3), 235-244.

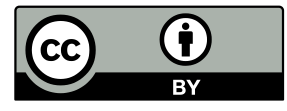

(C) 2021 by the author(s). Published by Annals of Contemporary Developments in Management \& HR (ACDMHR), under the terms and conditions of the Creative Commons Attribution (CC BY) license which can be accessed at http://creativecommons.org/licenses/by/4.0. 